\title{
Editorial
}

\section{Qualidade em tudo}

Silvio Gomes Monteiro

Hoje a palavra de ordem é Qualidade, procura-se ou se exige de tudo e de todos qualidade. No ambiente universitário se preocupa muito com a qualidade das pesquisa desenvolvidas nos diversos cursos de graduação, pós-graduação e nos laboratórios. Não é à toa que o Ministério de Educação e Cultura (MEC) tem criado critérios mais exigentes no credenciamento e recrediamento de Universidades.

Uma outra qualidade bastante investigada é a qualidade de vida, segundo a OMS, a definição de qualidade de vida é a "a percepção que um indivíduo tem sobre a sua posição na vida, dentro do contexto dos sistemas de cultura e valores nos quais está inserido e em relação aos seus objectivos, expectativas, padrões e preocupações". Trata-se de uma definição que contempla a influência da saúde física e psicológica, nível de independência, relações sociais, crenças pessoais e das suas relações com características inerentes ao respetivo meio na avaliação subjectiva da qualidade de vida individual. Neste sentido, poderemos afirmar que a qualidade de vida é definida como a "satisfação do indivíduo no que diz respeito à sua vida quotidiana".

Por isso que dos 11 artigos do O primeiro fascículo do volume 10 da Revista de Investigação Biomédica $(R / B)$, contém seis que estão avaliado qualidade de vida de certos grupos vulneráveis de pacientes, idosos ou com neoplasia ou a qualidade dos serviços oferecidos numa emergência. No atual fascículo de 2018 sete artigos originais abordaram os seguintes temas:

- Avaliação da autonomia funcional em idosos comunitários

- Risco de quedas pela fragilidade em idosos comunitários praticantes de atividade física

- Avaliação do nível de satisfação dos pacientes atendidos pela fisioterapia na Unidade de Saúde da Família do Pirapora

- Qualidade de vida em mulheres mastectomizadas

- Qualidade de vida em pacientes submetidos ao tratamento quimioterápico

- Perfil dos pacientes amputados por acidentes automobilísticos

- Efeitos do uso de um programa cinesioterapêutico na força de preensão manual de idosas

E há também três artigos de revisão, cujos temas abordados são:

- Atendimento e gestão como indicador de qualidade no serviço de emergência: revisão de literatura 
- Pneumonia bacteriana: aspectos epidemiológicos, fisiopatologia e avanços no diagnóstico

- Novas abordagens experimentais para o combate de infecções causadas por Staphylococcus aureus.

E um relato de caso sobre o uso de laminados cerâmicos em paciente com manchamento por tetraciclina.

Confiante na qualidade das pesquisas aqui impressas toda a equipe da $R I B$ deseja a todos os leitores essas boas leituras abram mais as vossas mentes para a realidade, como já dizia o próprio Albert Einstein.

Prof. Silvio Gomes Monteiro

Editor-Chefe 